\title{
Research on BIM implementation plan in construction enterprise
}

\author{
HE Guiyou ${ }^{1, a}$ and BIAN Li ${ }^{2, b}$ \\ ${ }^{1}$ School of Economics and Management, Tongji University, Shanghai, 200092, China. \\ ${ }^{2}$ Shanghai Electric Power Design Institute Co., Ltd., Shanghai, 200025, China \\ aheguiyou@163.com, biangrikuili@163.com
}

\begin{abstract}
Key Words: Building Information Modeling, implementation plan, construction enterprise
Abstract. To achieve the desired objectives for construction enterprise BIM implementation and depth implementation of management process and the project implementation, we explores the BIM implementation design principles and path. This paper proposed the BIM implementation roadmap for construction enterprise. Meanwhile, the construction enterprise BIM implementation strategy and detailed implementation plan are puts forward, which provides theory reference for construction enterprise BIM implementation.
\end{abstract}

\section{Introduction}

With the introduction and implementation of Building Information Modeling, BIM was seen as the second revolution after CAD technology in domestic construction industry [1]. As one of most important market subject in construction industry, construction enterprises were placed high hopes on BIM implementation. However, the actual implementation of BIM for construction enterprises is in a wait sate. In the light of innovation of BIM technology, how to promote construction enterprises BIM implementation has become a new issue of common concern in academic circles and industrial circles [2]. In this paper, BIM implementation of construction enterprise is as the main study object, focusing on the obstacles and ways. The main contents are as follows.

At present, Construction enterprise informatization is in a good external environment and the construction industry has set off a wave of BIM applications. During the rapid development of science and technology, the mechanical and electrical installation company has brought great changes and realized the great potential value and the importance of the implementation of BIM strategy. Most of the company leadership realized the importance of BIM implementation strategy and establish a special BIM organization, research laboratory to carry out BIM research activities, plans to implement the full implementation of BIM technology on all the company projects.

Based on the specific characteristics of BIM application and BIM technology, combined with the status quo of the company, this paper proposed the BIM implementation strategy for construction enterprise. The strategy focuses on the macro level strategic objectives and the micro level implementation plan, which is in order to promote the effective absorption of the BIM technology and guide project practice, enhance the core competitiveness of enterprises, the company.

This plan starts from the research of the company leadership and the implementation level, and obtains the capability level and resource allocation of the company in the implementation of BIM strategy, and then analyzes the status of the application of BIM, and then based on the current situation and industry development trend to develop the strategic objectives, set the cultivation period and the stage of development, and focus on the implementation plan of BIM (2015 -2016), and explore the development model of BIM. 


\section{BIM implementation status and future trend in construction industry}

The BIM implementation level in domestic construction industry is low [3]. $10 \%$ of the construction enterprises in the application of BIM technology which are mainly focus on large, complex projects. But in recent years, the project owners aware the potential value of BIM, such as Wanke, Wnada, SOHO etc. BIM Consultant Company, training institutions of various types, construction enterprises, government and industry association also pay more and more attention to the application of BIM.

Shanghai Center, Shanghai Disney Land and other large project use BIM during the lifecycle of project. Some projects also write BIM content into the tender and contract. So the BIM implementation ability is one of the essential condition of the enterprises participate in project competition.

Engineering Management Institute of Tongji University surveyed 11 typical construction enterprises in Shanghai. Based on the research results and S curve theory Which Rogers proposed, current BIM technology diffusion in China is still in the early stage (as shown in Figure 1-1). The application of BIM technology in China only used in few huge projects and some BIM uses. Many enterprises are still in a wait-and-see state, but it can be predicted that the diffusion rate of BIM technology will continue to improve in the future.

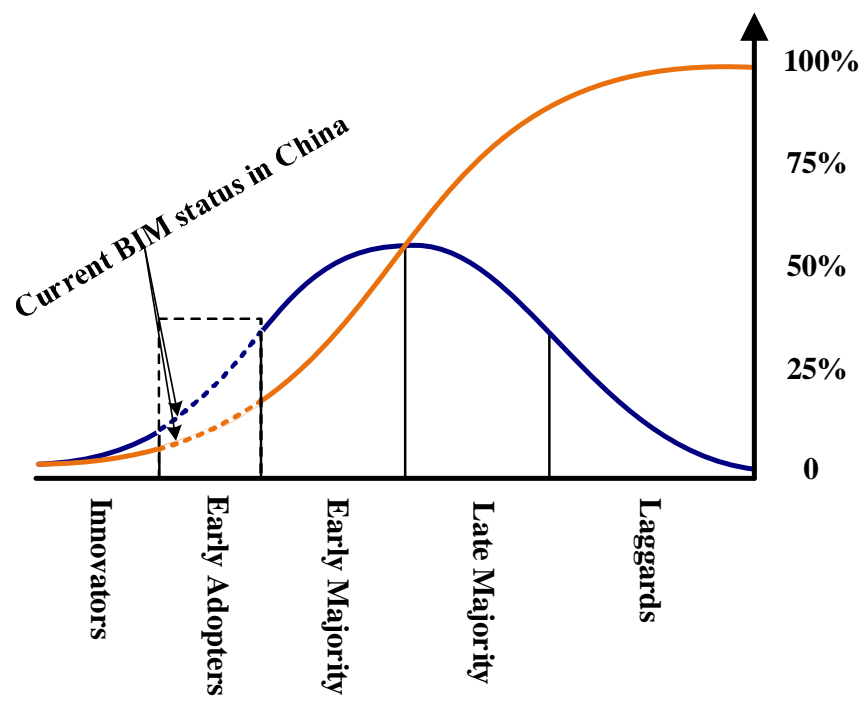

Figure 1-1 Current BIM technology diffusion status in China

\section{Strategic objective of BIM implementation}

Based on science and technology innovation and scientific management, BIM will support construction enterprise brand building and to be the BIM application leader among the general contractor. Through the integration of BIM technology and management, construction enterprise provide project lifecycle management services. Lighting the innovation and complexity of project practice, BIM application can support the influence and brand construction among the construction industry. 


\section{Implementation stage and roadmap}

Combine the domestic current situation of the BIM technology diffusion caused by the enterprise implementation of urgency, as well as to the BIM implementation research conclusion and proposed strategic goals. The Implementation stage could be divided into two phase implementation route.

\section{Ability construction period (2015-2016)}

(1) Cultivate the ability construction and market establish and total contract management service mode based on BIM.

1) Target by strengthening human resources and BIM facility, build the preliminary ability of BIM implementation.

2) Whole process of application of BIM implementation of construction project planning and management.

3) Through a typical project absorb preliminary BIM practice experience.

(2) Absorbing key technology and BIM tools, solve the development of BIM technology bottleneck and format BIM application technology advantage.

1) Solve the bottlenecks of key technology and tools in the process of enterprise development and improve company BIM implementation capacity;

2) Trying to implement BIM in large project practice, establish the leader role in the project practice and innovation of science and technology, and improve the image of the enterprise of science and technology.

3) All company's main business areas should be complete BIM implementation. Company has the capability of BIM applications and services at the end of 2016.

(3) Through typical project practice, BIM implementation case collection and marketing, cultivate advanced market in construction industry and establish the service mode.

1) Through BIM practice cases catalogued, focus on display BIM case implementation content, effect and the owners' satisfaction;

2) BIM technology gradually should be integrated into the company's existing business, and actively explore the BIM situation and total contract management service mode, which improve the service quality and market competitiveness of enterprises.

\section{Development target $(2017 \sim)$}

Through the introduction of BIM and associated technology upgrades, BIM technology will be integrated with project management information system and enterprise management information system, which will enhance the level of enterprise informationization and standardization. At the same time, construction enterprise should pay attention to market development and business innovation, and constantly improve the service quality, improve enterprise value. The company should aim to become the domestic mechanical and electrical contractor BIM implementation of enterprise and strive to dominate the general contractor management standard on the implementation of BIM. 


\section{Capability cultivation period implementation plan}

System and process management adaptation

The effective realization of the potential value of BIM technology depends on the communication, coordination and cooperation among the enterprises in the construction industry. The application of BIM technology needing the organization's internal integration environment, it is necessary to organize the application of the organization, and to change the way of the organization, and the extent of the adjustment of the organization. Based on the analysis of the current status of BIM application and its implementation of the project model and information, human resources status and other aspects of the analysis, we can set up a comprehensive BIM team, unified the BIM technology application for each sub company, the division of BIM technology to provide the support and background BIM technology support services.

\section{Establish information sharing mechanism}

Information sharing is the premise and foundation of BIM application. It has higher request to consistency of information, information accessibility, accessibility of information, the integrity of information, the level of detail of the information,, etc. Establishment of information sharing mechanism based on BIM can begin from the following two aspects.

(1) Information sharing in company level

Information sharing in company level are from project to branches, and then to the head office. Company plenary meeting regularly share the BIM implementation. Branch regularly report to the company within the scope of their respective business BIM implementation. Project department reports to the superior leadership.

(2) Information sharing in project level

Information sharing in project level is mainly between the members of the project department of BIM application situation, summary, analysis and communication. Can adopt the way a project department meetings is a good way for information sharing. Project members can discuss together based on BIM model and also can discuss the requirement of BIM model information. Meanwhile, information platform is the key to realize information sharing tools.

Information sharing in a variety of forms, but it is important to note the company level and project level must be in the process of information sharing information (paper documents, audio, data and video information, etc.) to organize and record volumes, for enterprise knowledge management and transfer.

\section{References}

[1] Eastman C, Teicholz P, Sacks R, Liston K. BIM handbook: A guide to building information modeling for owners, managers, designers, engineers, and contractors (2nd Edition) [M]. New Jersey: John Wiley \& Sons, Inc., 2011.

[2] National Institute of Building Science (NIBS). National BIM Standard. http://cic.vtt.fi/Projeets/vbe-net/data/BIM_Slide_Show.Pdf, 2013-09-07.

[3] Stephen A. Jones, Harvey M. Bernstein. The business value of BIM in north America multi-year trend analysis and user ratings (2007-2012) [R]. New York: McGraw-Hill Construction, 2013. 
